Sari Pediatri, Vol. 4, No. 4, Maret 2003: 180 - 185

\title{
Tata laksana Bayi dari Ibu pengidap HIV/AIDS
}

\author{
Rulina Suradi
}

Sejak diidentifikasi kasus AIDS pada tahun 1981 di Los Angeles, kasus AIDS melanda dunia. Di Asia Tenggara jumlah kasus yang dilaporkan pada tahun 1999 adalah 134.671 kasus. Di Indonesia secara kumulatif tercatat dari September 1987 sampai dengan Desember 2001 terdapat 1904 kasus HIV positif dan 615 kasus AIDS. Transmisi vertikal dari ibu ke bayi dapat secara transmisi intra-uterin, intrapartum dan melalui ASI. Dengan berbagai cara misalnya persalinan melalui bedah kaisar dan penggunaan obat obat antirertroviral terjadi pengurangan transmisi vertikal secara intra-uterin dan intrapartum, tetapi transmisi melalui ASI tidak dapat dicegah. Tata laksana bayi dari ibu pengidap HIV/AIDS adalah suportif, meliputi pemberian imunisasi rutin, pemantauan pertumbuhan dan pemeriksaan darah. Bila timbul gejala segera obati dengan obat antiretroviral.

Kata kunci: HIV/AIDS, transmisi intra-uterin, antiretroviral.

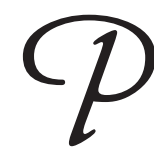

ada tahun 1981 di Los Angeles California, Amerika Serikat untuk pertama kali ditemukan suatu penyakit yang kemudian dikenal sebagai Acquired Immunodeficiency Syndrome atau AIDS. Penyebabnya adalah virus HIV tipe-1 yang baru dua tahun sesudahnya diindentifikasi. HIV/AIDS telah menjadi masalah dunia pada saat ini ${ }^{1}$. Di Asia Tenggara pada bulan Maret 1994 dilaporkan 5700 kasus HIV yang kemudian meningkat menjadi 65,091 kasus pada bulan Juli 1997 dan 134,671 kasus pada tahun $1999 .{ }^{2}$ Selama lebih dari 15 tahun adanya pandemi AIDS kurang lebih 9000 wanita di seluruh dunia telah terinfeksi HIV-1. Proporsi wanita yang terinfeksi HIV yang pada tahun 1990 hanya merupakan 25\% kasus meningkat menjadi $45 \%$ kasus pada tahun $1995^{3}$. Di Indonesia sampai September 1993 dilaporkan 175 kasus HIV-1 diantaranya $20 \%$ adalah wanita ${ }^{4}$. Kemudian dari April 1987 s/d

\footnotetext{
Alamat Korespondensi:

Dr. Rulina Suradi, SpA(K).

Subbagian Perinatologi. Bagian Ilmu Kesehatan Anak FKUI-RSCM. Jl. Salemba no.6, Jakarta 10430 .

Telepon: 021-3154020. Fax: 021-390 7743 .
}

Telah disampaikan pada Seminar HIV/AIDS, PIT POGI, Batu 2 Juli 2002
Desember 2001 secara kumulatif dilaporkan pengidap infeksi HIV dan kasus AIDS adalah 2,575 orang, 1904 kasus HIV positif dan 617 kasus AIDS. Selama tahun 2001 terdapat tambahan 951 kasus, 732 kasus terinfeksi HIV dan 219 kasus AIDS. ${ }^{5}$ Di Poliklinik kebidanan RS Dr. Cipto Mangunkusumo Jakarta sejak bulan April 1996 sampai dengan 19 Desember2001 tercatat 6 orang ibu yang memeriksakan kehamilannya ternyata mengidap HIV.

\section{Transmisi dari lbu ke Anak}

Sebenarnya ibu dengan HIV positif kurang begitu subur. Penelitian di Uganda dan beberapa negara maju menunjukkan bahwa infeksi HIV pada perempuan menurunkan fertilitas ${ }^{6}$. Namun karena kelompok umur yang terinfeksi HIV sebagian besar adalah usia subur maka kehamilan pada wanita HIV positif merupakan masalah nyata. Transmisi HIV dari ibu dengan HIV positif ke bayi disebut transmisi vertikal dapat terjadi melalui plasenta pada waktu hamil (intrauterin), waktu bersalin (intrapartum) dan pasca natal melalui air susu ibu (ASI). ${ }^{7}$ Tidak semua ibu pengidap HIV akan menularkannya kepada bayi yang dikandungnya. HIV tidak melalui barier plasenta. Transmisi vertikal terjadi 
sekitar $15-40 \%$, sebelum penggunaan obat antiretrovirus. Perbedaan ini terjadi karena perbedaan insidens pemberian ASI ${ }^{8,9}$ Diperkirakan risiko transmisi melalui ASI adalah 15\%. Apabila ibu terinfeksi pada saat hamil tua atau pada saat menyusui maka risiko tersebut meningkat sampai $25 \%{ }^{10}$

Mekanisme transmisi melalui ASI. HIV-1 berada di dalam ASI dalam bentuk terikat dalam sel atau virus bebas, namun belum diketahui bentuk mana yang ditularkan ke bayi. Beberapa penelitian yang perlu dikonformasi lagi oleh karena hanya melibatkan kasus yang tidak banyak memperlihatkan bahwa prevalensi dan konsentrasi DNA HIV-1 tertinggi pada 6 bulan pertama. Beberapa zat antibodi yang terdapat di dalam ASI dapat bekerja protektif terhadap penularan melalui ASI seperti laktoferin, secretory leukocyte protease inhibitor. Status vitamin A pada ibu juga penting karena terbukti laju penularan lebih tinggi pada ibu dengan defisiensi vit $\mathrm{A}^{10}$.

\section{Risiko transmisi vertikal}

Risiko transmisi vertikal bergantung pada beberapa faktor.

- Usia kehamilan. Transmisi vertikal jarang terjadi pada waktu ibu hamil muda, karena plasenta merupakan barier yang dapat melindungi janin dari infeksi pada ibu. Transmisi terbesar terjadi pada waktu hamil tua dan waktu persalinan.

- Beban virus di dalam darah.

- Kondisi kesehatan ibu. Stadium dan progresivitas penyaklit ibu, ada tidaknya komplikasi, kebiasaan merokok, penggunaan obat-obat terlarang dan defisiensi vitamin A.

- Faktor yang berhubungan dengan persalinan; seperti masa kehamilan, lamanya ketuban pecah, dan cara persalinan bayi baru lahir.

- Pemberian profilaksis obat antiretroviral

- Pemberian ASI

\section{Pencegahan transmisi vertikal}

\section{Pencegahan primer}

Pendekatan yang paling efektif untuk mencegah transmisi vertikal adalah pencegahan pada wanita usia subur. Konseling sukarela, rahasia, dan pemeriksaan darah adalah cara mendeteksi pengidap HIV secara dini.

\section{Pencegahan sekunder}

\section{a. Pemberian antiretrovirus secara profilaksis}

Pada tahun 1994 dapat dibuktikan bahwa pemberian obat tunggal zidovudine sejak kehamilan 14 minggu, selama persalinan dan dilanjutkan 6 minggu kepada bayi dapat menurunkan transmisi vertikal sebanyak 2/ 3 kasus $^{11}$. Akhir-akhir ini telah terbukti bahwa pemberian profilaksis zidovudine dalam jangka waktu lebih singkat cukup efektif asalkan bayi tidak diberikan ASI, oleh karena obat tersebut tidak dapat mencegah transmisi melalui ASI ${ }^{12}$. Saat ini penelitian membuktikan bahwa pemberian satu kali Nevirapine pada saat persalinan kepada ibu dan kemudian dilanjutkan dengan pemberian satu kali pada bayi pada usia 48-72 jam setelah lahir dapat menurunkan transmisi vertikal sebanyak $50 \%$ bila dibandingkan dengan pemberian zidovudine oral waktu intrapartum dan pada bayi selama satu minggu. ${ }^{13}$ Kombinasi dua obat antiretroviral atau lebih ternyata sangat mengurangi transmisi vertikal apalagi bila dikombinasi dengan persalinan melalui seksio sesaria serta tidak memberikan ASI. Efek samping penggunaan antiretroviral ini masih dalam penelitian.

\section{b. Pertolongan persalinan oleh petugas terampil}

Pertolongan persalinan sebaiknya oleh tenaga kesehatan yang terampil dengan meminimalkan prosedur yang invasif dan menetrapkan universal precaution untuk mencegah transmisi HIV.

\section{c. Pembersihan jalan lahir}

Pembersihan jalan lahir dengan menggunakan chlorhexidine dengan konsentrasi cukup pada saat intrapartum diusulkan sebagai salah satu cara yang dapat menurunkan insidens transmisi HIV intrapartum antara ibu ke anak. ${ }^{14,15}$ Selain menurunkan transmisi vertikal HIV tindakan membersihkan jalan lahir ini dapat menurunkan morbiditas ibu dan bayi serta mortalitas bayi. ${ }^{16}$

\section{d. Persalinan dengan seksio sesaria}

Suatu meta-analisis pada 15 buah penelitian yang melibatkan 7800 pasangan ibu anak membuktikan bahwa bayi yang dilahirkan secara seksio sesaria yang 
dilakukan sebelum ketuban pecah mempunyai kejadian transmisi vertikal jauh lebih rendah bila dibandingkan dengan kelahiran per vaginam. ${ }^{17}$ Sebuah penelitian klinik yang dilakukan dengan randomisasi membuktikan bahwa pada bayi yang dilahirkan dengan cara seksio sesaria transmisi vertikal HIV adalah $1.8 \%$ sedangkan yang lahir per vaginam transmisi vertikal adalah 10,6\%. ${ }^{18}$

\section{e. Menjaga kesehatan ibu}

Makanan ibu penting. Gangguan gizi ibu dapat merusak integritas mukosa usus dan memudahkan tranmisi. Selain vit. A, riboflavin dan mikronutrien lain dapat mempertahankan integritas mukosa usus.

\section{Tata laksana Bayi dari ibu HIV positif}

Pertolongan persalinan pada bayi baru lahir dari ibu yang mengidap HIV/AIDS seperti pada pertolongan persalinan normal dengan menerapkan universal precaution. Bila obat antiretroviral tersedia dapat diberikan kepada bayi. Saat ini obat yang dianjurkan untuk mengurangi transmisi vertikal pada neonatus adalah Zidovudine selama 6 minggu atau Niverapine sebanyak satu kali pemberian.

\section{Diagnosis HIV pada bayi}

\section{Pemeriksaan fisik}

Transmisi vertikal pada $50-70 \%$ terjadi sewaktu kehamilan tua atau pada saat persalinan sehingga pada waktu lahir bayi tidak menunjukkan kelainan. Jadi bila saat lahir tidak ditemukan kelainan fisik belum berarti bayi tidak tertular. Pemantauan perlu dilakukan secara berkala, setiap bulan untuk 6 bulan pertama, 2 bulan sekali pada 6 bulan kedua, selanjutnya setiap 6 bulan. Kelainan yang dapat ditemukan antara lain berupa gagal tumbuh, anoreksia, demam yang berulang atau berkepanjangan, pembesaran kelenjar, hati dan limpa serta ensefalopati progresif. Gejala juga dapat berupa infeksi pada organ tubuh lainnya berupa infeksi saluran nafas yang berulang, diare yang berkepanjangan, piodermi yang berulang maupun infeksi oportunistik antara lain infeksi dengan jamur seperti kandidiasis, infeksi dengan protozoa seperti Pneumocystis carinii, toxoplasma yang dapat memberi gejala pada otak. Bayi juga mudah menderita infeksi dengan miko-bakterium tuberkulosa.

\section{Pemeriksaan laboratorium}

a. Pemeriksaan darah tepi berupa pemeriksaan Hemoglobin, leukosit hitung jenis, trombosit, dan jumlah sel CD4. Pada bayi yang terinfeksi HIV dapat ditemukan anemia serta jumlah leukosit CD4 dan trombosit rendah ${ }^{19,20}$

b. Pemeriksaan kadar immunoglobulin. Ini dilakukan untuk mengetahui adanya hipo atau hiper gammaglobulinemia yang dapat menjadi pertanda terinfeksi HIV ${ }^{19,20}$

c. Pemeriksaan antibody HIV. Terdapatnya IgG antibodi HIV pada darah bayi belum berarti bayi tertular, oleh karena antibody IgG dari ibu dapat melalui plasenta dan baru akan hilang pada usia kurang lebih 15 bulan. Bila setelah 15 bulan di dalam darah bayi masih ditemukan antibodi IgG HIV baru dapat disimpulkan bahwa bayi tertular. Untuk dapat mengetahui bayi kurang dari 15 bulan terinfeksi atau tidak diperlukan pemeriksaan lain yaitu pemeriksaan IgM antibody HIV, biakan HIV dari sel mononuklear darah tepi bayi, mengukur antigen p24 HIV dari serum dan pemeriksaan provirus (DNA HIV) dengan cara reaksi rantai polimerase (polymerase chain reaction $=\mathrm{PCR})^{21}$.

Bila bayi tertular HIV in utero, maka baik biakan maupun PCR akan menunjukkan hasil yang positif dalam 48 jam pertama setelah lahir. Bila bayi tertular pada waktu intrapartum maka biakan HIV maupun PCR dapat menunjukkan hasil yang negatif pada minggu pertama. Reaksi baru akan positif setelah bayi berumur 7-90 hari ${ }^{21}$. Kebanyakan bayi yang tertular HIV akan menunjukkan hasil biakan dan PCR yang positif pada usia rata-rata 8 minggu. Dianjurkan untuk memeriksa PCR segera setelah lahir, pada usia 1-2 bulan dan 3-6 bulan.

\section{Tata laksana selanjutnya}

\section{Pengobatan antiretroviral}

Sampai sekarang belum ada obat antiretroviral yang dapat menyembuhkan infeksi HIV, obat yang ada hanya dapat memperpanjang kehidupan. Obat 
antiretroviral yang dipakai pada bayi/anak adalah Zidovudine ${ }^{22,23}$ Obat tersebut diberikan bila sudah terdapat gejala seperti infeksi oportunistik, sepsis, gagal tumbuh, ensefalopati progresif, jumlah trombosit < $75.000 / \mathrm{mm} 3$ selama 2 minggu, atau terdapat penurunan status imunologis. Pemantauan status imunologis yang dipakai adalah jumlah sel CD4 atau kadar imunoglobulin $<250 \mathrm{mg} / \mathrm{mm} 3$. Jumlah sel CD4 untuk umur $<1$ tahun, 1-2, 3-6, dan $>6$ tahun berturutturut adalah $<1750,<1000,<750 / \mathrm{mm} 3$., dan $<500 /$ $\mathrm{mm} 3$. Pengobatan diberikan seumur hidup. Dosis pada bayi $<4$ minggu adalah $3 \mathrm{mg} / \mathrm{kg} \mathrm{BB}$ per oral setiap 6 jam, untuk anak lebih besar $180 \mathrm{mg} / \mathrm{m} 2$; dosis dikurangi menjadi $90-120 \mathrm{mg} / \mathrm{m} 2$ setiap 6 jam apabila terdapat tanda-tanda efek samping atau intoleransi seperti kadar Hemoglobin dan jumlah leukosit menurun, atau adanya gejala mual.

Untuk pencegahan terhadap kemungkinan terjadi infeksi Pneumocystis carinii diberikan trimethropinsulfamethoxazole dengan dosis $150 \mathrm{mg} / \mathrm{m} 2$ dibagi dalam 2 dosis selama 3 hari berturut setiap minggu. ${ }^{22}$

Bila terdapat hipogammaglobulinemia ( $\mathrm{IgG}<250 \mathrm{mg} /$ dl) atau adanya infeksi berulang diberikan Imunoglobulin intravena dengan dosis $400 \mathrm{mg} / \mathrm{kg}$ BB per 4 minggu. Pengobatan sebaiknya oleh dokter anak yang telah memperdalam tentang pengobatan AIDS pada anak.

\section{Pemberian makanan}

Telah diketahui bahwa ASI mengandung virus HIV dan transmisi melalui ASI adalah sebanyak $15 \%$. Kemungkinan transmisi vertikal intrapartum dapat diturunkan sampai 2-4\% dengan menggunakan cara pencegahan seperti pemberian antiretrovirus, persalinan secara seksio sesaria, maka sebaiknya bayi tidak mendapat ASI. Namun perlu dipertimbangkan bahwa pemberian pengganti ASI jangan berdampak lebih buruk. Analisis dari data yang diperoleh membuktikan bahwa di negara yang angka kematian pascaneonatal adalah 90 per seribu, bila penggunaan susu formula mencapai $10 \%$ akan terjadi kenaikan $13 \%$ pada angka kematian bayi dan apabila penggunaan susu formula mencapai $100 \%$ angka kematian bayi naik sebanyak $59 \%{ }^{24}$. Penelitian lain menunjukkan bahwa di daerah dengan higiene yang buruk, angka kematian karena diare pada anak usia 8 hari sampai 12 bulan adalah 14 kali pada mereka yang tidak mendapatkan ASI dibandingkan yang mendapat ASI. Lagipula pada masyarakat yang kebiasaan menyusui itu lumrah, maka ibu yang tidak menyusui bayinya akan ketahuan bahwa ia menderita sesuatu sehingga tidak dibokehkan menyusui. Perlu dipertimbangkan juga biaya pengadaan makanan pengganti ini. Bila bayi tidak mendapat ASI maka susu formula yang dibutuhkan adalah: untuk 6 bulan pertama bayi membutuhkan sekitar 92 liter atau $20 \mathrm{~kg}$ susu. Pada usia antara $6-12$ bulan apabila makanan bayi masih $1 / 2$ diperoleh dari susu dan pada usia 12-24 bulan masih $1 / 3$ diperoleh dari susu maka antara 6-24 bulan susu formula yang dibutuhkan adalah 255 liter atau $43 \mathrm{~kg}$. Jadi dari 0 sampai 24 bulan dibutuhkan sekitar $63 \mathrm{~kg}$ susu formula ${ }^{25}$. Biaya tersebut cukup besar. Belum lagi biaya untuk air bersih dan bahan bakar dan biaya untuk perawatan kesehatan oleh karena bayi yang tidak mendapat ASI lebih sering sakit. Makanan yang dibuat sendiri akan lebih murah seperti yang dilaksanakan di Bangladesh biaya formula yang dibuat di rumah hanya $60 \%$ dari biaya susu kaleng. ${ }^{25}$ Maka apabila ibu bukan pengidap HIV/AIDS atau statusnya tidak diketahui maka ibu tetap dianjurkan untuk memberikan ASI

Apabila ibu diketahui mengidap HIV/AIDS terdapat beberapa alternatif yang dapat diberikan dan setiap keputusan ibu setelah mendapat penjelasan perlu didukung.

- Bila ibu memilih tidak memberikan ASI maka ibu diajarkan memberikan makanan alternatif yang baik dengan cara yang benar, misalnya pemberian dengan cangkir jauh lebih baik dibandingkan dengan pemberian melalui botol. Di negara berkembang sewajarnya makanan alternatif ini disediakan secara cuma-cuma untuk paling kurang 6 bulan.

- Bila ibu memilih memberikan ASI walaupun sudah dijelaskan kemungkinan yang terjadi, maka dianjurkan untuk memberikan ASI secara eksklusif selama 3-4 bulan kemudian menghentikan ASI dan bayi diberikan makanan alternatif. Perlu diusahakan agar puting jangan sampai luka karena virus HIV dapat menular melalui luka. Jangan pula diberikan ASI bersama susu formula karena susu formula akan menyebabkan luka di dinding usus yang menyebabkan virus dalam ASI lebih mudah masuk.

\section{Imunisasi}

Beberapa peneliti menyatakan bahwa bayi yang tertular HIV melalui transmisi vertikal masih mempunyai kemampuan untuk memberi respons imun terhadap 
vaksinasi sampai umur 1-2 tahun. Oleh karena itu di negara-negara berkembang tetap dianjurkan untuk memberikan vaksinasi rutin pada bayi yang terinfeksi HIV melalui transmisi vertikal. Namun dianjurakan untuk tidak memberikan imunisasi dengan vaksin hidup misalnya BCG, polio, campak. Untuk imunisasi polio OPV (oral polio vaccine) dapat digantikan dengan IPV (inactivated polio vaccine) yang bukan merupakan vaksin hidup. Imunisasi Campak juga masih dianjurkan oleh karena akibat yang ditimbulkan oleh infeksi alamiah pada pasien ini lebih besar daripada efek samping yang ditimbulkan oleh vaksin campak.

\section{Dukungan psikologis}

Selain pemberian nutrisi yang baik bayi memerlukan kasih sayang yang kadang-kadang kurang bila bayi tidak disusukan ibunya. Perawatan anak seperti pada anak lain. Hindari jangan sampai terluka. Bilamana sampai terluka rawat lukanya sedemikian dengan mengusahakan agar si penolong terhindar dari penularan melalui darah. Pakai sarung tangan dari latex dan tutup luka dengan menggunakan verban. Darah yang tercecer di lantai dapat dibersihkan dengan larutan desinfektans. Popok dapat direndam dengan deterjen. Perlu mendapat dukungan ibu, sebab ibu dapat mengalami stres karena penyakitnya sendiri maupun infeksi berulang yang diderita anaknya.

\section{Prognosis}

Tujuh puluh puluh delapan persen (78\%) bayi yang terinfeksi HIV sudah akan menunjukkan gejala klinis menjelang umur 2 tahun dan biasanya 3-4 tahun kemudian meninggal ${ }^{26,27}$

\section{Kesimpulan}

1. Neonatus dapat tertular HIV melalui transmisi vertikal sewaktu intranatal, intrapartum atau melalui ASI.

2. Transmisi vertikal dapat sangat dikurangi dengan pemberian obat antiretroviral pada ibu, persalinan melalui seksio sesaria dan pencucian jalan lahir.

3. Diagnosis dengan PCR dapat memastikan penularan pada usia 8 minggu.

4. Tatalaksana adalah seperti bayi yang tidak tertular dengan dukungan suportif berupa makanan bergizi dan pemberian imunisasi rutin.

5. Pemberian ASI tidak dianjurkan. Pengganti ASI ini harus diberikan secara gratis selama paling kurang 6 bulan. Namun apabila ibu tetap ingin memberikan ASI walaupun sudah dijelaskan sebelumnya tentang risikonya, ASI harus diberikan secara eksklusif selama 3-4 bulan saja.

6. Pemantauan dilakukan terhadap pertumbuhan dan perkembangan anak, serta pemeriksaan darah (hemoglobin, CD4, trombosit dan sebagainya)

7. Bila timbul gejala segera diobati dengan obat antiretroviral

8. Prognosis sampai saat ini masih kurang baik.

\section{Daftar Pustaka}

1. Loth G. The global programme on AIDS. Prosiding pada of the $5^{\text {th }}$ National Congress of the Indonesian Society for Perinatology and International Symposium, Lombok, Indonesia, September 4-7, 1994.

2. Narain JP. HIV/AIDS and sexually transmitted diseasesan update- WHO Regional Office for South East Asia, New Delhi, 1999.

3. Quinn TC, Global burden of the HIV pandemic. Lancet 1966; 348:99-106.

4. Abednego HM. Indonesia AIDS update, 15 September 1993. Disampaikan pada pertemuan Donor ke V, 29 September 1993, WHO, Jakarta.

5. Data dari laporan Pokdisus AIDS DepKes, 2002.

6. Desgree du LA, Msellati P, Yao A, Noba V, Viho I, Ramon R, et al. Impaired fertility in HIV-1 infected pregnant women : a clinical-based survey in Abyuan, Corte d'Ivoire 1997. AIDS; 13:517-21.

7. Newell ML. Mechanism and timing of mother-to-child transmission of HIV-1. AIDS, 1988, 12:831-37.

8. de Cock K, Fowler MG, Mercier E, de Vincenzi I, Saba J, Hoff. et al.Prevention of mother-to-child HIV transmission in resource-poor countries - translating research into policy and practice. JAMA, 2000, 283:1175-1182

9. Dabis F, Leroy V, Castetbon K, Spira R, Newell ML, Salamon R. Preventing mother-to child transmission of HIV-1 in Africa in the year 2000. AIDS, 2000; 14: 1017-26.

10. Van de Perre P: Transmission of HIV through breastfeeding: an overview . dalam HIV and Infant Feeding : Implementation of Guidelines, A report of the UNICEF-UNAIDS-WHO Technical consultation on HIV and Infant feeding Geneva, 20-22 April 1998.

11. Connor AM, Sperling RS, Gelber Rl, Kiselev P, Scott G, O'Sullivan MJ, et al. Reduction of maternal-infants transmission of human immunodeficiency virus type 1 with zidovudine treatment. New England Journal of Medicine 1994; 331:1173-1180. 
12. Wiktor SZ, Ekpini E, Karon JM, Nkengasong J, Maurice C, Severin ST, et al. Short course oral zidovudine for prevention of mother-to-child transmission of HIV-1 in Abidjan. Cote d'Ivoire: a randomized trial . Lancet 1999; 353: 781-785.

13. Anderson J. The Hopkins HIV Report July 2001 - Perinatal Transmission and HIV http://www.hopkinsaids.edu/publications/report/july01_3.html

14. Biggar RJ, Miotti PG, Taha TE, Mtimavalye L, Broadhead R, Justesen A, et al. Perinatal intervention trial in Africa: effect of a birth canal cleansing intervention to prevent HIV transmission. Lancet 1996; 347: 1647-1650.

15. Gallard P,Mwanyumba F, Verhofstede C, Claeys P, Chohan V, Goetghebeur,E, et al.. Vaginal lavage with chlorhexidine during labour to reduce mother-to-child transmission: clinical trial in Mombasa, Kenya. AIDS, 2001; 15:389-396.

16. Taha TE, Biggar RJ, Broadhead L, MtimavalyeLAR, Miotti PG,, Justesen AB et al. Effect of cleansing the birth canal with antiseptic solution on maternal and newborn morbidity and mortality in Malawi: clinical trial. BMJ, 1997; 315:216-220.

17. The International Perinatal HIV Group NEJM 1999; 340:9770.

18. The European Mode of Delivery Collaboration. Lancet 1999; 353:1035
19. Gibb D, Newell ML. HIV infection in children. Arch Dis Child 1992; 67:138-141.

20. Amman AJ. Human Immuno Defiency Virus infection / AIDS in Children: The Next Decade. Pediatrics 1994; 93:930-935

21. Lane HC and Davey RT. Diagnosis of HIV Infection. Immunol Allergy Clin N Amer. 1995; 15:2 :367-237.

22. Pizza PA. Pediatric AIDS : Part I Medical Management of HIV-infected Children. AIDS Clinical Care 1993; 5:9-10

23. Working group on antiretroviral therapy : National Pediatric HIV resource Center. Antiretroviral therapy and medical management of the human immuno deficiency virusinfected child. Pediatric Infect Dis J. 1993; 12:513-522

24. Savage F. Replacement feeding options. Dalam HIV and Infant Feeding : Implementation of Guidelines, A report of the UNICEF-UNAIDS-WHO Technical consultation on HIV and Infant feeding Geneva, 20-22 April 1998.

25. Lhotska L. Cost of replacement feeding. Dalam HIV and Infant Feeding : Implementation of Guidelines, A report of the UNICEF-UNAIDS-WHO Technical consultation on HIV and Infant feeding Geneva, 20-22 April 1998.

26. Falloon J, Eddy J, Winer L and Pizzo PA. Human immunodeficiency virus infection in Children. J Perdiatr 1989:1-30.

27. Prober CG, Gehrson AA. Medical Management of newborns and infants born to immunodeficiency virus- seropositive mothers. J Pediatr Infect Dis 1991; 10:684-695 